\title{
An Investigation in IT Projects Failure within Kurdistan Regional Government of Iraq
}

\author{
Bakhtiar M. Amen \\ Dept. of Informatics, \\ School of Computing and \\ Engineering \\ University of Huddersfield United \\ Kingdom
}

\author{
Rebwar M. Nabi \\ Department of IT \\ Computer Science Institute \\ Sulaimani Polytechnic University, \\ Sulaimani, Iraq
}

\author{
Sardasht M. Mahmood \\ Statistics and Computer Dept. \\ College of Commerce \\ University of Sulaimani \\ Sulaimani, Iraq
}

\begin{abstract}
The importance of information technology (IT) system has extremely become crucial for governments to reduce routines, improve transparency, systemize governmental processes, easy internal communications and enhance productivity. For these reasons, most developed countries are extremely relying on increasing IT projects to provide better services for their citizens and to enhance collaboration between their directories. The aim of this paper is to identify primarily causes of several IT projects failures with Kurdistan Regional Government (KRG) and comparative with several other IT projects success and failure within developed countries such as Turkey, UAE and Estonia. Although, we are aiming to introduce and draws the gaps between IS design in KRG-IT projects factors in terms of culture, social, political and lack of experts were they have had a vital impacts on the KRG-IT projects failure. In This paper we have proposed a qualitative research approach to analysis the results and discover the reasons behind the failures. Furthermore, this study attempts to provide better solutions and recommendations to emphasis high-risk prototypes that affected IS in developed countries.
\end{abstract}

\section{General Terms}

Your Information Systems, Management of Information Systems, Information Technology, IT project Failure.

\section{Keywords}

IT Projects; Project Management; Success and Failure; Management Failures; Information Technology; IT-KRG, Kurdistan IT Projects

\section{INTRODUCTION}

Today the importance of IT projects and E-government has become incredibly crucial to establish a robust, flexible, dynamic and scalable infrastructure. E-government is powerful tool to increase citizens' trust and confidence in their governments. The e-government enables to provide benefits from time consuming, cost effectiveness, high quality standards across the government departments and best practices sharing [1] [7] [16]. Information Technology (IT) strategy is one of the fundamental rules of IT Project success or failure [2] [11]. The Kurdistan Regional Government1 (KRG) rapidly increasing economy built

${ }^{1}$ Kurdish population is 5.2 million and divided on by four governorates of Erbil, Slemani, Duhok and Halabja with approximately 40,000 square kilometers [15]. This includes the governorates administered by the Kurdistan Regional Government upon progressive economic policies and growing government simplicity, investment opportunities within every sectors, including oil and gas, electricity, agricultural and Information Technology (IT) sectors. The KRG's progress development must become compatible with new economy realities. Therefore, IS was one of the aims of KRG government to concern about and this drives KRG to develop department of IT within KRG in 2007. KRG-IT department implemented and announced several projects as we depicted in figure 1, includes implementing MS office license for KRG directories [4]. In fact, one of these projects was succeeded and several were either disconnected or failed according to head of the KRG-IT department interview in [4].

To observe this, evidence of information system known as integrated set of components from collecting, storing, processing, and communicating information. Generally, success is defined as "the system achieved what was intended of it; it was operational at the time and cost that were planned" [8]. Nevertheless, Sauer in [8] defined the failure "an information system should only be deemed a failure when development or operation ceases, leaving supporters dissatisfied with the extent to which the system has served their interests".

This paper clarifies the interconnection between different factors where acknowledged to individually affect the egovernment implementations, thus enabling the disambiguation between the primary and secondary less effective causes of failure. This paper is intents to identify in a more conclusive ways of the reasons behind projects failure within KRG-IT department and comparative those reasons with adopted IT projects in developed countries. Moreover, the identified failure causes results have been compared with our IT core factors and analysis the results against each factors in order to emphasis the relationship between the different factors from the qualitative research method.

\subsection{IT Projects within KRG}

Since 2007 KRG-IT department implementing several projects including; government staffs an Electronic ID Card with budget of $(\$ 4,712,031)$, this project was aimed to provide 600,000 standards, professional, biometric and smart ID card for KRG employees, until now 2014 they were enables to provide only 6,000 IDs and the project has

but does not include areas of Kurdistan outside of KRG administration, such as Kirkuk. 
been suspended. The Second project was IOpenKRG known as (E-government) implemented from 2007 and suspended 2 years later in 2009 , the aim of this project was 'to implement ICT as tool to facilitate and enhance better government services and enhance citizen's life through electronic public services' [17] with budget of $(\$ 3,535,206)$. The third project was KRG-IT strategy and infrastructure [13] [14], this project was aimed to develop an IT plans for KRG ministries within next five years with budget of $(\$ 3,500,000)$. In fact, this project managed to complete without been agreed to be accepted by KRG. The fourth project was known as IT academy, this project attempted to provide training and education to the KRG employees in order to enhance their capabilities of IT knowledge with budget of $(\$ 4,250,000)$ with KOICA cooperation [13] [14].

Furthermore, the total KRG-IT projects cost were about 16 million dollar within 5 years boundaries, Figure 1 predicted the overall projects.

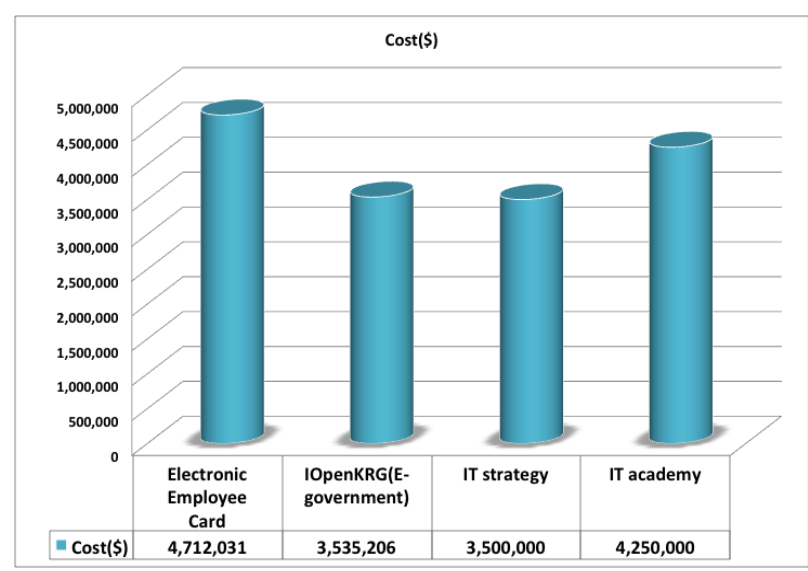

Fig 1: Details of KRG-IT projects

In addition, KRG has had a contract with Microsoft to purchase MS window and office License for $(\$ 6,826,832)$ before established KRG-IT Department from 2005, as yet known these license were all expired without providing any benefits to the KRG. Although, above mentioned projects have not yet been officially finalized by the government. Based on the assumptions of lack of official announcement of finishing projects, the failure of those IT projects can be identified.

\section{LITERATURE REVIEW}

Scope, time and cost are the fundamental elements of projects quality measurement and performance [12] [20] [21]. In fact, resources and specifications design to meet customer requirements are also considered as important elements within IT project [3] [10]. Thus, the IT project manager should carefully balance between these crucial elements in order to achieve high customer satisfaction.

The project scope, cost and time achievable through successful project management according to [5] and the project management has been defined as a set of tools, techniques and knowledge. According to Gartner study about the failure rate of IT project which has been adopted in five different countries, the failure rate of small projects usually recorded less compared to midsize and large IT projects [18]. Furthermore, in [3] [5] [10] studies demonstrates that $52.7 \%$ of the IT projects were not been completed on time and also were over cost. Meanwhile,
$31.1 \%$ have not met the project scope. Projects usually are classified into three main types known as projects success, project challenged and projects impaired [3].

Furthermore, there are several core factors that can be classified within each project known as success, failure and challenged as depicted in Figure 2. However, it is widely known that there is not consistent definition of what comprises of IT project success and failure among studies in [19] [20] hence the comparison and generalization found to be complicated. Furthermore, the success of an IT project would be determined at the beginning of the project's implementation in terms of critical thinking, planning, budget, clear project scope, clear project vision, objectives and user involvement.

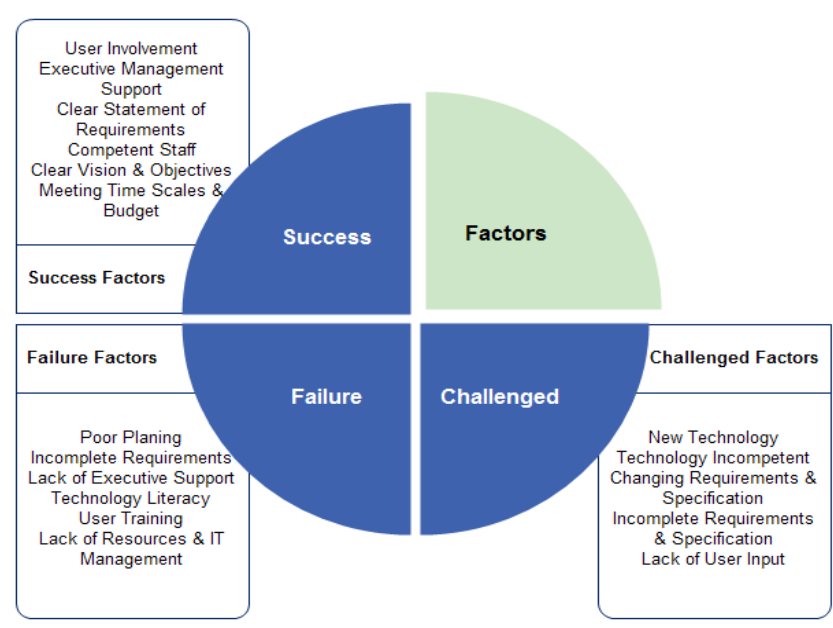

Fig 2: Core Factors for IT Projects

In addition to above all, recent studies demonstrate that several IT projects have been failed within most of sectors around different countries Table 1 depicts some of the projects with their costs. While each project has been named from the following table in terms of cost estimated and project types.

Table 1. Recent IT Survey Projects Failure

\begin{tabular}{|c|c|c|c|}
\hline Year & $\begin{array}{l}\text { Project Name \& } \\
\text { Country }\end{array}$ & Cost & Project Type \\
\hline 2014 & $\begin{array}{l}\text { The Affordable Care } \\
\text { Act - MNsure (USA) }\end{array}$ & $\begin{array}{c}\text { \$150 } \\
\text { Million }\end{array}$ & $\begin{array}{l}\text { e-Commerce } \\
\text { marketplace }\end{array}$ \\
\hline 2013 & $\begin{array}{l}\text { The Digital Media } \\
\text { Initiative (UK) }\end{array}$ & $\begin{array}{c}£ 100 \\
\text { Million }\end{array}$ & $\begin{array}{l}\text { Digital } \\
\text { archive }\end{array}$ \\
\hline 2012 & $\begin{array}{c}\text { Mobile Information } \\
\text { Programme (MIP)(UK) }\end{array}$ & $\begin{array}{c}£ 103 \\
\text { Million }\end{array}$ & $\begin{array}{c}\text { Mobile } \\
\text { computing } \\
\text { implémentatio } \\
\mathrm{n}\end{array}$ \\
\hline 2011 & $\begin{array}{l}\text { Law enfoncement } \\
\text { assistance program } \\
\text { (Australie) }\end{array}$ & $\begin{array}{c}\$ 100 \\
\text { Million }\end{array}$ & LINK \\
\hline 2010 & $\begin{array}{l}\text { Virtual border control } \\
\text { system (UK) }\end{array}$ & $\begin{array}{c}\$ 1 \\
\text { Billion }\end{array}$ & $\begin{array}{l}\text { Secure Border } \\
\text { Initiative } \\
\text { Network }\end{array}$ \\
\hline 2009 & Marine One (USA) & $\begin{array}{c}\$ 13 \\
\text { Billion }\end{array}$ & $\begin{array}{l}\text { Monitoring } \\
\text { and Safety }\end{array}$ \\
\hline
\end{tabular}


Internal and external sources of information with third parties involvement are found to have a great impact on project success or fail. In fact, National Institute of Standards and Technology (NIST) reported that software defects cost nearly $\$ 60$ billion annually and British Computer Society (BCS) with an estimated of 12.4 billion software project failure yearly [9]. However, in [19] stated that "The management of information technology (IT) projects is a challenging task with many projects failing to achieve their intended objectives". Therefore, high level of attention and accuracy have to be considered from top level managers down to extraordinary employees to guarantee the success of the project from the beginning to the end.

\section{METHODS}

This study was carried out in two main phases, which are conducting a questionnaire and an interview. Whereas, we found qualitative research approach isthe most appropriate approach to be conducted in this paper due to the nature of the data sources that we have collected from both forms of questionnaire, interview and related organised resources [6].

\subsection{Final Questionnaire}

A questionnaire was sent to relate IT departments within the KRG ministries as well as to a group of University professors and lecturers. Meanwhile, the questionnaire was distributed to the Kurdistan provinces, universities, general directories, and IT Department (KRG-IT). Moreover, the questionnaire was designed to investigate the current status of the IT projects and services by KRG and to discover the reason behind the failure of the IT project in KRG.

The questionnaire was designed into three sections. Firstly, thirteen questions related to general information have been gathered about participant's work place, responsibilities within their IT units and project that they were involved. Secondly, this section was based on project evaluation that consist of six questions which are rated based on scale of 1 to 6 as satisfied level. The third section was provided to an open question about the participant's suggestion to improve IT projects in the future.

\subsection{Theoretical Interview}

NRT TV based another phase of collecting data on a TV interview with former head of KRG-IT directorate. In the interview he has discussed those four essential IT projects and other KRG project related to IT deployment with detailed explanations. Furthermore, other parts of the interview were included projects status; budget, start dates, deadlines, the project external vendors, government funding and those problems have faced them during the implementation of the projects.

\section{RESULTS}

The structure of the questionnaire addressed several questions and it was distributed and emailed to related IT employees in the KRG ministries and directories. The questionnaire covered key questions regarding IT projects in the KRG and the reasons behind the failure of these projects.

The total participants were 200 and have been divided by 18 ministries and general directories in KRG. The $86.5 \%$ of the directories in the ministries have established IT unit and $58 \%$ have more than 100 employees. The majority of respondents were from ministry of higher education and scientific research with IT specialty. Moreover, the $13.8 \%$, $38.1 \%, 5 \%$ and $43.1 \%$ of the participants were from IT manager, IT employee, IT support and maintenance and other positions respectively.

Almost half of the employees have indicated that they have not yet issued ID card with $59.5 \%$ while the other participants have ID card with $40.5 \%$. Meanwhile, several participants indicated that their ID card has been expired. Furthermore, numbers of employees were applied for obtaining ID card whereas surprisingly the project has been suspended by the government.90.5\% of the respondents have strongly denied the existence of e-government in the Kurdistan as illustrated in the figure 3 .

Do you think E-Government exists in KRG?

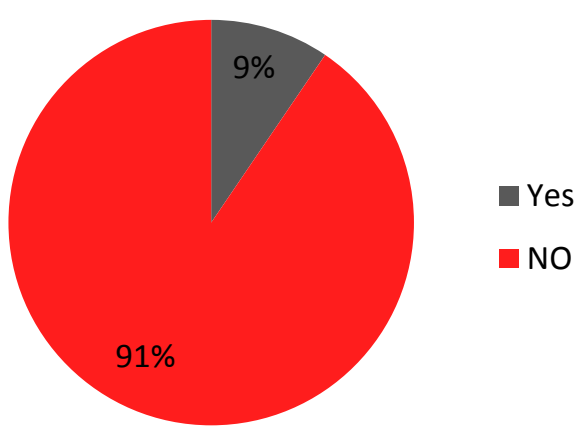

Fig 3: existence of E-Government

Figure 4 illustrates the department of KRG-IT services and projects in KRG. An overwhelming majority of the respondent $51.5 \%$ were heard about Employee ID card project. Almost $46 \%$ participants were not aware of any of KRG-IT Department services and projects. Moreover, the IT strategy has been selected as least known IT projects among respondents with $9 \%$.

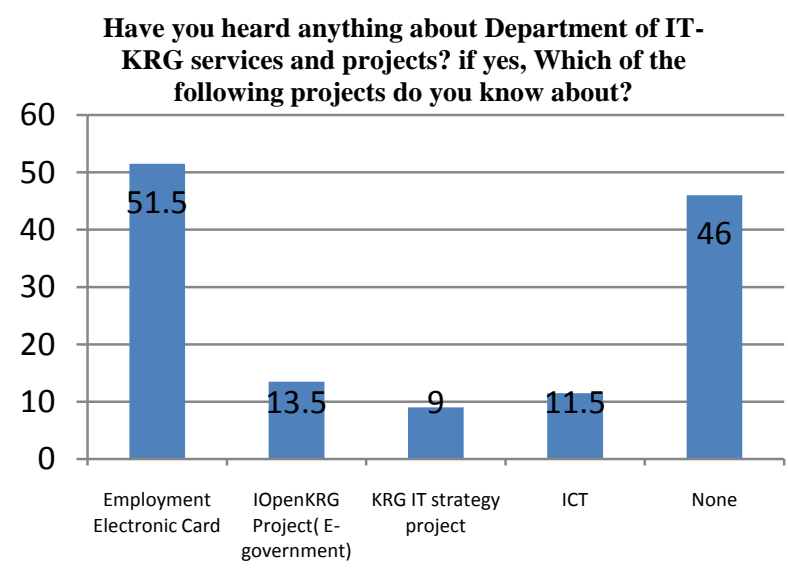

Fig 4: Dept. of KRG-IT Services and Project in KRG

A high number of the directories $67.3 \%$ mentioned that they are receiving Internet from third parties and the Fibre-optic cable service was not reached yet as shown in figure 5 . 
Do you have Fibre optic network in your organization?

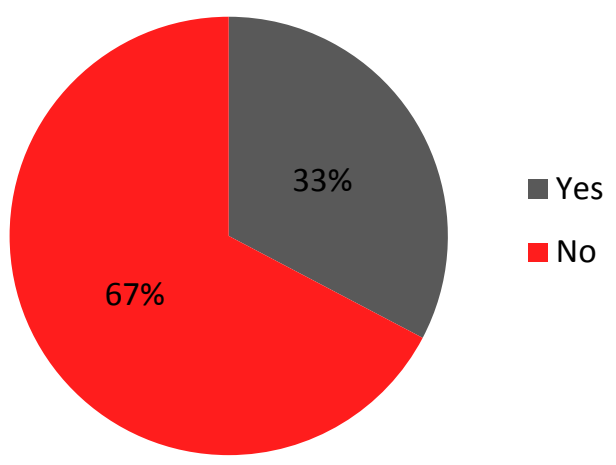

Fig 5: Reachable level of Fibre-optic cable service

In particular, $86 \%$ of respondents strongly stated that the KRG-IT projects were failed in advance as shown in the figure 6 .

Do you think that the IT projects and ITKRG projects especially have failed?



Fig 6: Failure rate of IT projects

Figure 7 demonstrates the reasons behind the IT project failure. Common reasons for KRG-IT projects failure were: the poor planning was indicated as the most common factor for the project failure with $76.7 \%$. Furthermore, some received comments about the failure reasons found to be useful such as:

- $\quad$ Lack of well-qualified IT expert in top executive managers

- Poor communication and corporation between the Department of KRG-IT and the government

- The existence of corruption in the department of KRG-IT

- Monopolising the department of KRG-IT by political parties

- Lack of trust between the government and the department of KRG-IT

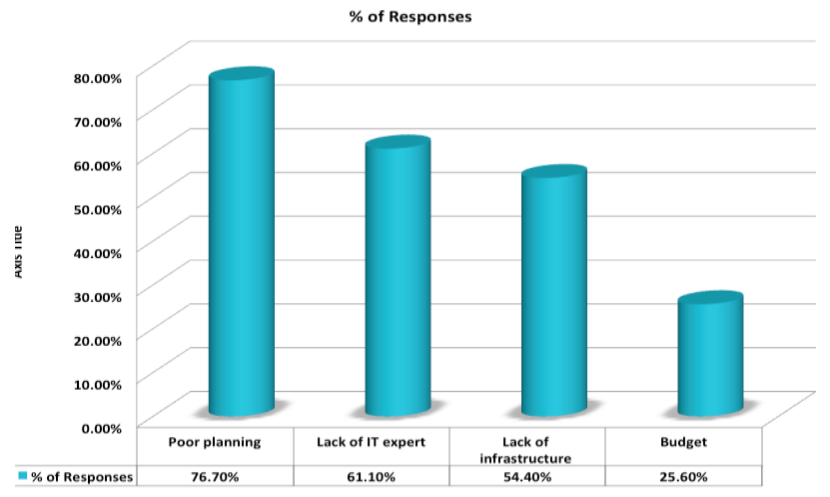

Fig 7: Projects Failure Factors

Many recommendations for the IT project success were mentioned by the respondent the top five were:

- Develop network and communication services by improving Fibre-optic cable for all ministries and directories

- Proving the fixed budget for IT projects in the annual budget by the government

- Avoid political involvement in the projects

- Import IT experts and consultants from developed countries

- Culture awareness and enhance IT literacy

- Establish Council of IT consultants in the KRG

Table 2 demonstrates the evaluation of KRG-IT in different important aspects. The perception of respondent was measured based on several factors in scale variable from 1 to 5 as very unsatisfied to very satisfy.

Table 2. KRG-IT Projects and Services Evaluation

\begin{tabular}{|c|c|c|c|c|c|}
\hline \multirow[t]{2}{*}{ Questions } & \multicolumn{5}{|c|}{ Satisfied Level (\%) } \\
\hline & 1 & 2 & 3 & 4 & 5 \\
\hline $\begin{array}{l}\text { KRG-IT services } \\
\text { and projects }\end{array}$ & $\begin{array}{c}28 . \\
5\end{array}$ & 48.5 & 19.5 & 3 & 0.5 \\
\hline $\begin{array}{l}\text { KRG-IT security } \\
\text { and privacy }\end{array}$ & 17 & 26 & 40.5 & 15 & 1.5 \\
\hline Proper planning & $\begin{array}{l}26 . \\
63\end{array}$ & 50.25 & 18.09 & 3.52 & 1.51 \\
\hline $\begin{array}{c}\text { Projects support } \\
\text { and improve IT in } \\
\text { KRG }\end{array}$ & $\begin{array}{c}10 . \\
5\end{array}$ & 25.5 & 30.5 & 29.5 & 4 \\
\hline $\begin{array}{c}\text { Political impact on } \\
\text { projects }\end{array}$ & $\begin{array}{l}12 . \\
50\end{array}$ & 11 & 16.5 & 32 & 28 \\
\hline $\begin{array}{l}\text { Importance of } \\
\text { E-government }\end{array}$ & 6 & 2.5 & 5.5 & 11 & 75 \\
\hline
\end{tabular}




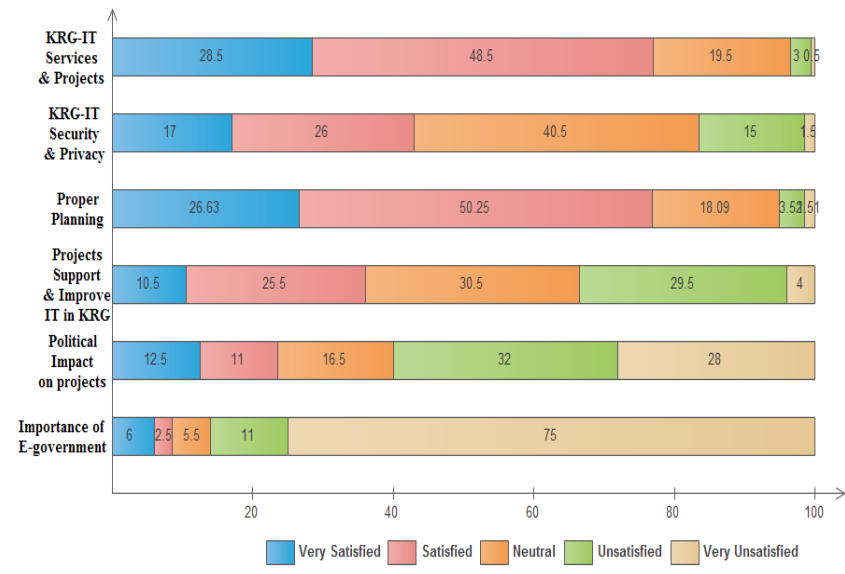

Fig 8: KRG-IT Projects and Services Evaluation

\section{DISCUSSION}

In this section we discuss our results and describe the result interpretation and result implication.

\subsection{Result Interpretation}

The results of qualitative and quantitative along with theoretical interview of our study are very encouraging. It widely accepted that having IT units is remarkably crucial to undertake, maintain and supervise IT related tasks and projects in KRG ministries and directories. Although, $13.5 \%$ of respondents stated that IT unit is not exists in their organizations.

According to the interview, the former head of the KRG-IT department mentioned that the Smart ID Card project has been officially finished to create smart for 600,000 employees while $59.5 \%$ of participants (Employees) indicated that they have not been issued the card yet. Meanwhile, majority of respondents $(51.5 \%)$ selected as well-known projects among other projects in KRG. However, some employees mentioned that their ID cards have been expired and they were not able to renew the card due to the suspension process of the project by the government. Based on this assumption, the failure of the project can be stated.

The e-government term can be broadly known as a communication channel between government and facilitate citizen's requirements [7]. Based on the importance of egovernment, $90.5 \%$ of the respondents were replied that the e-government does not exist in KRG. While an overwhelming majority of the respondents $(75 \%)$ were indicated with the importance of e-government. In fact, the cost of IOpenKRG project was 3,535,206\$ funded by Italian Government and KOIKA company according to the TV interview and KRG-IT annual report. Moreover, it is important to note that the first instalment budget has been funded. Meanwhile, the project outstanding budget has not been made due to some of the crucial factors includes: fibre, second instalment budget, and open source technology. Accordingly, $74.4 \%$ of respondents believed that the budget was not the major cause of the failure rather lack of IT expert $(61.1 \%)$, effective planning $(76.7 \%)$, and lacks of IT infrastructure $(54.4 \%)$ were the main factors behind the failure.

The IT strategy project is also considered as outstandingly vital projects to have clear road map toward bright future of IT in KRG. Therefore, the KRG-IT department launched and completed the IT strategy project with 3,500,000\$ funded by the government with third party constancy vendor $(\mathrm{PwC})$ [13]. On the other hand, the government has not accepted the project. The possible reasons might be the absence of trusted relationship between the government and the KRG-IT department. Likewise, politics and culture are key critical factors for the acceptance failure as can be seen from the figure $9,32 \%$ of respondents believed that the politics play a key role in succession of projects in KRG.

\section{How Satisfied that politic has impact on projects} completion?



Fig 9: Politic Impact on Project Completion

IT academy training center was established to provide training and education to the KRG employees in order to enhance the administration efficiency. Nevertheless, the center has been acknowledged by only $88 \%$ of respondents. MS Windows and Office license was also launched and completed by the government with budget $6,500,000 \$$. The project had to provide 30,000 licenses while only 10,000 licenses have been ready to be used by the government ministries and departments. The absence of critical communication between KRG-IT department and ministries resulted in the failure of the project failure.

\section{MANAGERIAL IMPLICATION}

The outcomes and insights from this study shows the remarkably need for particular kinds actions from the government to rectify the IT project failures. Importantly, this study also indicates that the government should:

- Establish a managing committee (by government) which involving group of top managers, IT experts and professional IT consultants

- Installing and completing Fibre-optic projects soon as possible

- Develop and improve IT literacy in the society especially among the Ministers, General Advisors, top managers and to the ordinary citizens

- Conducting conferences, symposiums, workshop and seminars to demonstrate the importance of IT in the organisations

- Provide Professional training and certification for the managers, employees by importing international experts in IT projects to Kurdistan. Because currently having certifications become compulsory in IT world and they are a proof of knowledge and capability in specific area of Technology. 
- Documentation process should be in place in accordance international standards to be used when new manager taking responsibility

\section{CONCLUSION}

This paper investigated the current status of IT projects in Kurdistan Regional Government (KRG). Identified the reasons behind the incompletion of mentioned projects. Finally provides concrete solutions as well as recommendation to minimize the risk of the project failures in the future compare to other developed countries. The results of the 200 respondents as well as an interview have been proposed for the reasons behind of uncompleted. At the meantime, there were some suspended projects by the government. At the end, the result of this study has proven that one project has been completed and used officially which known as IT academy for the training.

The results indicate that the main reasons of the KRG-IT projects failure are:

- Poor planning

- $\quad$ Lack of IT expert

- Lack of infrastructure (Fibre Optic, IT literature, Data centers, Equipment, Licensed software)

Based on literature, it can be identified that the factors of user involvement, proper planning, good leadership, and IT infrastructure have a great impact on success of the projects.

This study recommends that the government should avoid the political involvement in the IT projects and apply the good project management practices to reduce the failure projects factors, which discussed earlier.

Admittedly some limitations should be acknowledged. We were unable to interview the managers who are or have responsible of IT projects. Overwhelming attempts have been tried to interview the former prime minister, who have been accused to suspend most of the projects by IT-KRG department. Moreover, the former General Director and current manager of IT-KRG department had been contacted to participate in the interview but they refused. Therefore, further research and studies can be done to involve top politician who behinds the establishment, launching and suspending IT projects in the KRG. Additionally, a research can be also conducted to investigate the reason behind of suspension of the IT strategy project as well as why the government has suspended the Smart ID card project.

\section{ACKNOWLEDGMENTS}

We thankfully appreciate with permission for using the former KRG-IT director's interview in the NRT-TV channel. Finally, we would like to our gratitude to the KRG-IT Sulaimani branch for providing their annual report.

\section{REFERENCES}

[1] AlSuwaidi, A. \&Rajan, V., (2013). 'E-government failure and Success Factors Rank Model an extension of Heeks Factor Model', Current Trends in Information Technology (CTIT), International Conference on 2013, vol., no., P.161,165. [Online] Availableat:URLhttp://ieeexplore.ieee.org/stamp/stam p.jsp?tp $=\&$ ar $\quad$ number $=6749495 \&$ isnumber $=6749463$ [Accessed 10 July 2014].
[2] Atkinson, J.\&Jourdan, C. (2008). A practical guide to risk assessment, How principles-based risk assessment enables organizations to take the right risks. PricewaterhouseCoopers

[3] Attarzadeh, I. and HockOw, S. (2008) 'Project Management Practices: The Criteria for Success or Failure,' Communications of the International Business Information Management Association (IBIMA), vol. 1, p.234-241

[4] Barashkwai, BotanMahmood (2012) Kurdistan:NRT, 2nd March, [Streaming video file]. Available at: http://nrttv.com/barnamakan-details.aspx ?jimare $=1094$ [Accessed 28th February 2011].

[5] Charvat, J. (2003) Project Management Methodologies: Selecting, Implementing, and Supporting Methodologies and Processes for Project. New Jersey: John Wiley \& Sons, Inc.

[6] Dawson, C. (2009) Projects in Computing and Information Systems A Student's Guide. $2^{\text {nd }}$ ed. England: Addison-Wesley, Pearson Education Limited

[7] Elkadi, H. (2014). 'Success and failure factors for egovernment projects: A case from Egypt', Egyptian Informatics Journal, Vol 14, (2), P. 165-173. [Online] Availableat:http://www.sciencedirect.com/science/arti cle/p ii/S1110866513000236_ [Accessed 10 July 2014]

[8] Fortune, J. and Peters, G. (2005) Information systems Achieving Success by Avoiding Failure.England: John Wiley \& Sons, Ltd

[9] Galorath, D. (2012). 'Software Project Failure Costs Billions.. Better Estimation \& Planning Can Help' [Online] Available http://www.galorath.com/wp/software-projectailurecosts-billions-better-estimation-planning-canhelp.php_ [Accessed 11 November 2014].

[10] Gray, C. F. and Larson, E. W. (2008). Project Management: The managerial process. 4th Edition, Singapore: McGraw-Hill Educations.

[11] Heeks, R.(2002). 'InformationSystemsandDeveloping Countries: Failure, Success, andLocalImprovisations', The Information Society. Vol. 18, Iss. 2, 2002

[12] Jayawardena, R. and Perera, M. (2010) 'Project success factors for Information Technology (IT) related solution deployments; a study conducted for Sri Lankan IT vendors,' ICIAfS10, IEEE. P.453-458

[13] KOICA, (2012). Ex-post Evaluation Report for the projects of establishing ICT training center, KOICA: Korea

[14] KRG-IT Department, (2010), Annual report 2010, KRG-IT Department, Hawler-Kurdistan.

[15] Krg.org, (2014). The Kurdistan Region in Brief[online]Availableat:http://www.krg.org/p/p.aspx?1 $=12 \& \mathrm{~s}=020000 \& \mathrm{r}=300 \& \mathrm{p}=210 \quad$ [Accessed 23 Nov. 2014].

[16] Lootah, R. Geray, O. (2006). 'Dubai eGovernment Case Study', OECD / UNDP Meeting: Dubai 
[17] Mahmood, Z. (2013). "E-Government Implementation and Practice in Developing Countries." IGI Global, 2013. 1-348. [Online] Available at:doi: 10.4018/9781- 4666-4090-0[Accessed 23 Nov. 2014].

[18] Mieritz, L. (2012). Gartner Survey Shows Why Projects Fail[online] Available at: $\mathrm{http} / / / \mathrm{www}$.learninhandteaching.info/learning/cognitiv e. Html [Accessed 10July 2014].

[19] Standing, C.,Guilfoyle, A., Lin, C. and Love, P. (2006), 'The attribution of success and failure in IT projects,' Industrial Management \&DataSystems.vol. 106 (8), p. 1148-116. Emerald Group Publishing Limited.
[20] Vit, G.(2011). 'Competing logics: Project failure in Gaspesia', European Management Journal, Vol 29, (3), P. 234-244. [Online] Available at: http://www.sciencedirect.com/science/article/pii/S026 3237310000873 [Accessed 10 July 2014].

[21] Wyngaard, C., Pretorius, H. and Pretorius, L. (2011) 'Strategic management of the triple constraint tradeoff dynamics - a polarity management approach, Industrial Engineering and Engineering Management (IEEM), IEEE International Conference. P.824- 